See Article page 1864 .

\section{Commentary: Should patients awaiting cardiac surgery who need anticoagulation be on direct oral anticoagulants or vitamin K antagonists?}

\author{
Rizwan A. Manji, MD, PhD, MBA, a,b and \\ Rakesh C. Arora, MD, PhD ${ }^{\mathrm{a}, \mathrm{b}}$
}

Direct oral anticoagulant (DOAC) prescriptions increased 233 -fold over 7 years partly due to the convenience benefits (standardized dosing, minimal/no drug interactions and no need for monitoring) of these drugs. ${ }^{1,2}$ However, questions subsequently arose about the data and the analysis in DOAC studies $^{3}$; drug and food interactions became apparent ${ }^{2,4,5}$; and thrombosis and bleeding problems occurred. ${ }^{2,6}$ In fact, 2 companies have already paid more than $\$ 1.4$ billion in lawsuits over harms caused by DOACs. ${ }^{7}$

In this issue of the Journal, Fox and colleagues ${ }^{8}$ describe a perioperative anticoagulation management strategy with associated postoperative outcomes in patients undergoing elective cardiac surgery. Patients were either on preoperative DOACs, preoperative vitamin $\mathrm{K}$ antagonists, or no preoperative anticoagulation. The authors observed that a DOAC level below $<30 \mathrm{ng} / \mathrm{mL}$, which was a median of 3.8 days from last dose, was associated with comparable bleeding and secondary outcomes to patients on traditional vitamin $\mathrm{K}$ antagonists. Although the authors have provided important data relating specifically to cardiac surgery patients, questions remain. It is still unclear what serum DOAC level is safe. When data from the study by Fox and collègues are examined, ${ }^{8}$ measured DOAC levels

From the ${ }^{\mathrm{a}}$ Department of Surgery, Max Rady College of Medicine, University of Manitoba, Winnipeg; and ${ }^{\mathrm{b}}$ Cardiac Sciences Program, St. Boniface Hospital, Winnipeg, Manitoba, Canada.

Disclosures: Dr Arora has received an unrestricted educational grant from Pfizer Canada Inc and honoraria from Mallinckrodt Pharmaceuticals and Edwards Lifesciences for work unrelated to this work. Dr Manji has nothing to disclose with regard to commercial support.

Received for publication Dec 24, 2019; revisions received Dec 24, 2019; accepted for publication Dec 26, 2019; available ahead of print Jan 21, 2020.

Address for reprints: Rizwan A. Manji, MD, PhD, MBA, I.H. Asper Clinical Research Institute, St Boniface Hospital, CR 3014-369 Tache Ave, Winnipeg, Manitoba R2H 2A6, Canada (E-mail: rmanji@sbgh.mb.ca).

J Thorac Cardiovasc Surg 2021;161:1876-7

$0022-5223 / \$ 36.00$

Copyright (c) 2020 by The American Association for Thoracic Surgery

https://doi.org/10.1016/j.jtcvs.2019.12.102

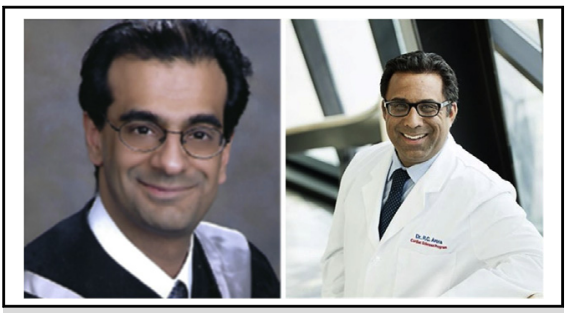

Rizwan A. Manji, MD, PhD, MBA (left), and Rakesh C. Arora, MD, PhD (right)

CENTRAL MESSAGE

Until there are readily available

tests and standardized reference

ranges for direct oral anticoagu-

lants, perhaps coumadin should

be used for anticoagulation for

patients awaiting cardiac surgery.

were low, with a median value of 0 for most categories. Thus, is 3.8 days of withholding DOACs too long in patients with a greater risk of thromboembolic events? In contrast, Douketis and colleagues ${ }^{4}$ demonstrated holding DOAC for only 2 days (level $<50 \mathrm{ng} / \mathrm{mL}$ ) in high-risk surgery (such as cardiac surgery) provided acceptable bleeding rates. Of note, Fox and colleagaues ${ }^{8}$ did find that only $71 \%$ of patients stated the last dose of DOAC they took and $69 \%$ of patients with high DOAC levels were still taking their DOAC despite being told to stop. Thus, measuring levels was very important.

DOACs have specific assays with specific reagents, and these are not readily available. ${ }^{2,9}$ In addition, at present there are no standardized guidelines or therapeutic ranges established for what DOAC level to aim for particular operations. ${ }^{2,9}$ Although reversal agents for DOACs are now on the market, there are issues with cost and efficacy. ${ }^{2,10}$ Even though there are problems with coumadin, such as need for monitoring, food/drug interactions, and nonstandardized dosing, some of these problems appear to be arising for DOACs as well. However, for coumadin, there are easily and widely available tests with reference ranges to measure the degree of anticoagulation, there are effective reversal methods, and the costs to the patient/health care system are minuscule (at least 40-fold lower for coumadin vs DOAC). ${ }^{1,2,11}$ Until more information is available on DOACs, it may be appropriate to manage patients awaiting cardiac surgery who require anticoagulation with coumadin. 


\section{References}

1. Ting C, Fanikos C, Fatani N, Buckley LF, Fanikos J. Use of direct oral anticoagulants among patients with limited income and resources. J Am Coll Cardiol. 2019;73:526-8

2. Eckert JC, Fugh-Berman A, Krensky S, Mendola ND, Wood SF. Impacts of pharmaceutical marketing on healthcare in the District of Columbia: the marketing and prescribing of anticoagulants in the District of Columbia. Milken Institute School of Public Health. The George Washington University. Sponsored by District of Columbia Department of Health, Health Regulation and Licensing Administration. 2018. Available at: https://dchealth.dc.gov/sites/default/files/ $\mathrm{dc} /$ sites/doh/publication/attachments/Impacts \% 20Report \% 202018\%20-\%20 FINAL.pdf. Accessed November 28, 2019.

3. Cohen D. Concerns over data in key dabigatran trial. BMJ. 2014;349:g4747.

4. Douketis JD, Spyropoulos AC, Duncan J, Carrier M, Le Gal G, Tafur AJ, et al. Perioperative management of patients with atrial fibrillation receiving a direct oral anticoagulant. JAMA Intern Med. 2019;179: 1469-78.

5. Vranckx P, Valgimigli M, Heidbuchel H. The significance of drug-drug and drug-food interactions of oral anticoagulation. Arrhythm Electrophiosol Rev. 2018;7:55-61.

6. Hassan K, Bayer N, Schlingloff F, Oberhoffer M, Wohlmuth P, Schmoekel M, et al. Bleeding complications after use of novel oral anticoagulants in patients undergoing cardiac surgery. Ann Thorac Surg. 2018;105:702-8.

7. Thomas K. Bayer and Johnson \& Johnson settle lawsuits over Xarelto, a blood thinner, for $\$ 775$ million. New York Times. March 25, 2019. Available at: www.nytimes.com/ 2019/03/25/health/xarelto-blood-thinner-lawsuit-settlement.html. Accessed November 28, 2019.

8. Fox V, Kleikamp A, Dittrich M, Zittermann A, Flieder T, Knabbe C, et al. Direct oral anticoagulants and cardiac surgery: a descriptive study of preoperative management and postoperative outcomes. J Thorac Cardiovasc Surg. 2021;161: 1864-74.e2.

9. Tripodi A, Braham S, Scimeca B, Moia M, Peyvandi F. How and when to measure anticoagulant effects of direct oral anticoagulants? Practical issues. Pol Arch Intern Med. 2018;128:379-85.

10. Connolly SJ, Milling TJ Jr, Eikelboom JW, Gibson CM, Curnutte JT, Gold A et al. Andexanet alfa for acute major bleeding associated with factor Xa inhibitors. N Engl J Med. 2016;375:1131-41.

11. Ziakas PD, Kourbeti IS, Poulou LS, Vlachogeorgos GS, Mylonakis E. Medicare part D prescribing for direct oral anticoagulants in the United States: cost, use and the rubber effect. PLoS One. 2018;13:e0198674. 